\title{
Nursing and mental health: a reflection in the midst of the coronavirus pandemic
}

\author{
Enfermagem e saúde mental: uma reflexão em meio à pandemia de coronavírus
}

Enfermería y salud mental: una reflexión en medio de la pandemia de coronavirus

\section{Maria de Lourdes Custódio Duarte Daniela Giotti da Silva ${ }^{b}$ Mariana Mattia Correa Bagatinic}

How to cite this article: Duarte MLC, Silva DG, Bagatini MMC. Nursing and mental health: a reflection in the midst of the coronavirus pandemic. Rev Gaúcha Enferm. 2021;42(spe):e20200140. doi: https://doi.org/10.1590/19831447.2021.20200140
Universidade Federal do Rio Grande do Su (UFRGS), Escola de Enfermagem, Departamento de Assistência e Orientação Profissional. Porto Alegre, Rio Grande do Sul, Brasil.

Universidade Federal do Rio Grande do Sul (UFRGS) Escola de Enfermagem, Curso de Graduação em Enfermagem. Porto Alegre, Rio Grande do Sul, Brasil. "Universidade Federal do Rio Grande do Sul (UFRGS), Escola de Enfermagem, Programa de Pós-Graduação em Enfermagem. Porto Alegre, Rio Grande do Sul, Brasil.

\section{ABSTRACT}

Objective: To reflect on the mental health of Nursing professionals in the context of the coronavirus pandemic.

Method: This is a theoretical-reflective study based on the discursive formulation on the theme and supported by the national and international scientific literature and by the authors' critical analysis.

Results: The analyzed studies, along with the care practice, showed that Nursing professionals are susceptible to the exacerbation of symptoms such as depression, anxiety, insomnia, anguish, and stress in the midst of the coronavirus pandemic, in view of their exhaustive work shifts, patients'deaths, risk of infecting themselves and their families, and social isolation.

Final considerations: The mental health of Nursing professionals needs to be listed as one of the priorities for health managers, guaranteeing strategies and public policies that ensure sanity for those who are in the front line of the fight against the pandemic. Keywords: Nursing. Mental health. Coronavirus infections. Pandemics. Adaptation, psychological.

\section{RESUMO}

Objetivo: Refletir sobre a saúde mental dos profissionais de enfermagem no contexto na pandemia de coronavírus.

Método: Estudo teórico-reflexivo baseado na formulação discursiva acerca da temática, sustentado pela literatura científica nacional e internacional e análise crítica dos autores.

Resultados: Os estudos analisados, somados à prática assistencial, têm evidenciado que os profissionais de enfermagem são suscetíveis à exacerbação de sintomas como depressão, ansiedade, insônia, angústia, estresse, em meio à pandemia de coronavírus, tendo em vista os turnos exaustivos de trabalho, a morte de pacientes, risco de autocontaminação e de seus familiares e isolamento social.

Considerações finais: A saúde mental dos profissionais de enfermagem necessita ser elencada como uma das prioridades para os gestores de saúde, garantindo estratégias e políticas públicas que assegurem a sanidade para estes que estão na linha de enfrentamento da pandemia.

Palavras-chave: Enfermagem. Saúde mental. Infecções por coronavírus. Pandemias. Adaptação psicológica.

\section{RESUMEN}

Objetivo: Reflexiones sobre la salud mental de los profesionales de Enfermería en el contexto de la pandemia de coronavirus. Método: Estudio teórico-reflexivo basado en la formulación discursiva sobre el tema respaldada por literatura cientíica nacional e internacional y por el análisis crítico de los autores.

Resultados: Los estudios analizados, sumados a la práctica asistencial, demuestran que los profesionales de Enfermería son susceptibles a la exacerbación de síntomas como depresión, ansiedad, insomnio, angustia y estrés en medio de la pandemia de coronavirus, en vista de los exhaustivos turnos de trabajo, la muerte de los pacientes, el riesgo de autocontaminación y de contagio de sus familias y el aislamiento social.

Consideraciones finales: La salud mental de los profesionales de Enfermería debe figurar como una de las prioridades para los gerentes de salud, garantizando estrategias y políticas públicas que aseguren la salud de quienes están en la primera línea de lucha contra la pandemia.

Palabras clave: Enfermería. Salud mental. Infecciones por coronavirus. Pandemias. Adaptación psicológica. 


\section{口INTRODUCTION}

The disease called Coronavirus Disease-19 (COVID-19) was first notified in December 2019 in a group of people linked to a seafood market in Wuhan, southern China. Subsequently, the number of infected patients increased exponentially in the Asian continent ${ }^{(1)}$.

The first COVID-19 case in the American continent was reported on January $19^{\text {th }}, 2020$, in the state of Washington, USA, and, five days later, there was the first case in Europe, more specifically in Bordeaux, France. On February $26^{\text {th }}$, the Brazilian Ministry of Health $(\mathrm{MoH})$ reported the first case of COVID-19 in the city of São Paulo. In was only on March $11^{\text {th }}$, 2020, that the World Health Organization (WHO) declared the situation as a pandemic. On April 16 ${ }^{\text {th }}, 2020$, the number of confirmed cases worldwide surpassed two million, and the number of deaths exceeded 130,000. On that same day, Brazil had 30,425 confirmed cases and 1,924 deaths ${ }^{(1)}$.

The significant number of cases requiring hospitalization, including admission to Intensive Care Units (ICUs), as well as the lack of effective and safe pharmacological treatments, such as medications or vaccines, has raised concerns about the collapse of the health system in different countries. Afterwards, the WHO advocated fundamental measures of social distancing and hand hygiene as the most efficient actions to reduce the impact of the pandemic ${ }^{(2)}$.

These measures are estimated to "flatten the infection curve" by lowering the peak of incidence, reducing the risk of shortage of hospital beds, ventilators, and others supplies due to the sudden increase in their demand, which would be associated with greater mortality ${ }^{(1)}$.

This disease has a broad clinical spectrum, ranging from flu-like symptoms like cough and fever to severe pneumonia that can lead to death. The worst clinical outcomes are proportionally related to people of advanced age and with other comorbidities, such as cardiovascular diseases, diabetes, chronic respiratory diseases, and cancer ${ }^{(1-2)}$.

Some initiatives on the theme had already been developed by the MoH, although the first COVID-19 case was confirmed in Brazil only at the end of February. However, the major measures were implemented after the launch of the Coronavirus prevention advertising campaign ${ }^{(3)}$.

The high transmissibility caused many health professionals to be infected worldwide, due to the vulnerability of their work activities. In Brazil, the situation is not different, and the verified occurrence of cases among these professionals is one of the major concerns of the Unified Health System (Sistema Único de Saúde, SUS)(4).

Working in the midst of a pandemic requires the professionals and health services to have a strong structure capable of commanding and controlling decision-making and information, allowing these professionals to face the pandemic in the best possible manner. In the front line against COVID-19, professionals from all over the world experience exhaustive work shifts, acting both in the care of more complex cases and in health prevention ${ }^{(5)}$.

The exposure of the health professionals to the virus in the direct care of patients has an influence on their mental health, affecting the work processes and the personal lives of these workers. In this sense, a study conducted in China with 1,257 health professionals (physicians and nurses), in 34 hospitals that received COVID-19 patients, reveals that a significant number of these professionals reported symptoms related to depression $(50.4 \%$,$) , anxiety (44.6\%),$ insomnia (34.0\%), and anguish (71.5\%). The symptoms were more significant among women nurses, who were directly engaged in the diagnoses, treatments, or care for patients with suspected or confirmed Coronavirus infection ${ }^{(6)}$.

In this context, the performance of the Nursing team stands out. In addition to being in the front line, nurses have extenuating workdays, handle patients' secretions, and are perhaps the professionals who spend more time next to people admitted due to the disease. In addition, they face scarcity of Personal Protective Equipment (PPE), continuously deal with death, and experience social distancing and fear of contaminating their family members when they return to their homes. Thus, it is worth asking: How is the mental health of these professionals in the context of the COVID-19 pandemic?

This reflection foresees the need of addressing the theme of the mental health of these professionals in the context of the current pandemic.

\section{OBJECTIVE}

To reflect on the mental health of the Nursing professionals in the context of the Coronavirus pandemic.

\section{METHOD}

This is a theoretical-reflective study based on the discursive formulation of the theme and supported by the national and international scientific literature and by the authors' critical analysis. The search was conducted on the SciELO, PubMed, and LILACS electronic databases from April to June 2020. The selection of the descriptors used in the review process was conducted by searching the following Health Science Descriptors (Descritores em Ciências da Saúde, DeCS): Enfermagem (Nursing), Pandemia (Pandemic), Saúde Mental (Mental Health), and Infecções por Coronavírus (Coronavirus 
Infections). The following inclusion criteria were considered: articles available in full text, written in Portuguese, English or Spanish, published from 2019 to 2020, and that answered the guiding question of the study.

This search procedure initially identified 125 publications potentially eligible for this manuscript. After the first analysis, with title evaluation, 98 were considered for the second phase, which consisted in reading the abstracts; subsequently, those studies that met inclusion criteria were read in full. In the end, 9 articles (SciELO - four articles, PubMed - four articles, LILACS - one article) met all the criteria and supported the present reflection.

A document from the Inter-Agency Standing Committee (IASC) and another from the WHO were also included, as they were deemed relevant for the theme. Considering the normative format restrictions for this journal, only indispensable publications were selected as references. It is emphasized that the reflections to be made resulted from the interpretations of the literature and also from the authors' reflective impressions.

\section{Reflecting on the mental health of the Nursing professionals in the midst of the pandemic}

The current scenario made health professionals and services to reinvent themselves, requiring the reorganization of their work activities. They mobilized by prioritizing the urgency and emergency cases and postponing elective consultations and/or procedures, thus directing attention and available resources to face the pandemic $\mathrm{C}^{(7)}$.

The first professionals to fight against COVID-19 were the health workers from Wuhan, who demonstrated work performance with high risk of infection, inadequate protections, overwork, discrimination, lack of contact with their families, and exhaustion to face a disease with large-scale transmissibility ${ }^{(8)}$. Such situations, experienced in other countries, revealed the reality of the health professionals and triggered other organizational structures to deal with the Brazilian reality in a different manner.

New services were opened in the country, such as field hospitals, increasing the capacity of the SUS to receive patients. Thus, many managers needed to invest in the emergency hiring of professionals to cover a significant staff shortage in most of the health institutions.

Bearing this is mind, the MoH launched a strategic action entitled "Brasil conta comigo - Profissionais da Saúde" ("Brazil relies on me - Health Professionals") at the beginning of April, in order to register and qualify professionals willing to act against COVID-19 in the country, at the full disposal of federal, state, district, and municipal managers of the SUS ${ }^{(4)}$.
In this context, the Nursing Federal Council (Conselho Federal de Enfermagem, COFEN) published Resolution 634/2020(9) to authorize and normalize Nursing teleconsultation, as a way to fight the Coronavirus pandemic, by means of consultations, clarifications, referrals, and guidelines on the use of information and communication technology media. The emergence of this action coincides with the strengthening of the Nursing actions, showing the importance of these practices in the care provided to the population.

The search for valuing the health workers and the concern with exposure increased the prominence of professionals other than physicians (who already historically have great visibility among the population), such as physical therapists, nurses, and nursing technicians. In Brazil and worldwide, the Nursing team is in the front line against the Coronavírus and has an important role at all levels of care, making their presence indispensable in the fight against COVID-19 and in the care of infected patients.

It is interesting to highlight that in 2020, considered the year of Nursing, when the world leaders recommended that the profession becomes central in the health policies with the establishment of programs for the development of Nursing leaders, such as the Nursing Now campaign, the professionals face the sad reality of the COVID-19 pandemic. However, the campaign is increasing the visibility of the health professionals and revealing weaknesses that expose them to risky situations such as work overload, unhealthy environments, daily exposure to the virus, and lack of appreciation for the profession, with a negative impact on their physical and mental health ${ }^{(4)}$.

Due to the nature of the patient-centered Nursing work in primary, secondary, and tertiary care settings, there are occupational risks; therefore, it is essential that these workers receive the necessary supplies for their protection when handling infected patients ${ }^{(5)}$. Nevertheless, it is known that, in view of the current scenario, there is PPE shortage, and the general population is being instructed to wear tissue face masks, because disposable masks need to be reserved for these professionals. In addition to that, PPE shortage is also a source of fear and anguish for the team.

Therefore, the biosafety measures became stricter than usual, which may cause increased physical tension resulting from the use of the protective equipment, keeping the professionals in a constant state of attention and vigilance. Consequently, these workers are subjected to stricter procedures, which can inhibit their autonomy and spontaneity ${ }^{(10)}$.

In this scenario, the workers are afraid of and concerned with what is to come. In some countries, the infection rates double every 24 hours, which leads to an increase in the anxiety felt by the general population. Stress symptoms, 
high absenteeism, sadness, fatigue, anxiety, and seclusion seem to have become part of the work routine. In addition, for nurses working in sectors like emergency departments and ICUs, death can represent failure and is also a source of stress and anguish ${ }^{(7)}$.

Both the professionals in the front line and those working in other sectors can experience psychological distress and may require a temporary leave of absence. In this sense, it is worth mentioning the phenomenon known as "vicarious traumatization", in which people who did not directly experience a trauma develop psychological symptoms resulting from their empathy with those who did. Thus, when they need to be away from their work functions, the workers tend to report feelings of guilt, anger, frustration, and sadness ${ }^{(1)}$.

Protecting the Nursing team is equally necessary for the care provided to the patients because, if these workers are unable to perform their activities, who will be responsible for providing health care? The Nursing team is exposed during their entire workday due to their direct contact with patients, and every worker who gets sick poses a risk for the population, because their absence reduces by one the number of professionals, overloading the teams that continue to fight against the virus ${ }^{(4)}$.

Brazil reported the first death of a nursing technician due to COVID-19 in April and, since then, there has been an increase in the number of health professionals with suspected or confirmed infection, as well as in the number of deaths. Reports to the relevant bodies, such as the COFEN and the Nursing Regional Councils (Conselhos Regionais de Enfermagem, COREN), revealing the use of inadequate materials for patient care, are scaring and predict an even greater increase in the rates of Coronavirus infection among these workers ${ }^{(11)}$.

A shortage of nurses for the care of COVID-19 cases is already predicted in Brazil. In this sense, the Ministry of Education approved, according to Ordinance No. 374, of April $3^{\text {rd }}, 2020^{(12)}$, the early graduation of Nursing students and of other health courses, such as Pharmacy, Physiotherapy, and Medicine during the pandemic period, on an exceptional basis, in order to contribute to the staff of professionals in the fight against the disease.

However, the following question arises: If the care provided to COVID-19 patients requires qualified professionals, how to demand technical competence from new workers if they have not completed the entire course? Furthermore, if professionals with a longer training time continuously face death and, even so, many have their mental health impaired, how is it possible to expect recent graduates to be prepared? How to support them?

In the midst of the chaos experienced during a pandemic, it is essential that the health authorities are prepared to deal in the best manner possible with the consequences that the virus can cause in people, including problems related to their mental health. Currently, it is expected that they know how to manage the situation, being flexible and adjusting conducts according to the complexity of the disease ${ }^{(13)}$.

The Nursing teams working in the emergency sectors and in ICUs usually experience tense moments; however, the intensification of tasks, the demand for positive results, and social expectation on their work hamper their ability to fully perform their work activities, since these events have an impact both on their mental health and on their human relationships. Furthermore, many professionals have been harassed by some managers to continue care, even under precarious work conditions ${ }^{(11)}$.

In addition to the fight for better working conditions and protection of the professionals with comorbidities, the COFEN platform provides online free support, acknowledging the importance of preserving mental health at this moment $t^{(9)}$. However, it is known that many workers are still unaware of this support, while others ignore their mental health impairment.

In addition to that, the professionals directly involved in the treatment of COVID-19 end up suffering social stigmatization, which contributes to greater social isolation and triggers anguish in relation to the high risk of contamination and to the fear of infecting family members ${ }^{(1,13)}$.

In this sense, a review addressing the mental health problems faced by the health professionals due to the COVID-19 pandemic shows that they present a considerable level of stress, anxiety, depression, and insomnia ${ }^{(14)}$. These symptoms are probably related to the stigma that the Nursing professionals have direct contact with infected patients, as well as to the greater demand in the work environment, the increased number of patients under their care, and the need for constant update ${ }^{(10)}$.

It is known that the health situation in Brazil was already very demanding for the Nursing professionals before the current scenario, exposing them to working conditions far from ideal. What emerges now is a movement by managers in the search of offering basic resources to guarantee that these professionals continue working during one of the most complex periods in the Brazilian health scenario. However, at what cost? At the cost of the mental health of many professionals who work tense, anguished, and experiencing many occupational risks?

Beyond physical health, the mental health of these professionals must in fact be included in the agenda of the health managers, since it is being directly compromised.

In pandemics, the number of people with mental health impairment can usually be greater than the number of people affected by the infection, and these implications may last 
longer and have higher prevalence than the traumatic event itself. High rates of anxiety and stress symptoms, in addition to those of mental disorders and post-traumatic stress, have been reported in the professionals, mainly among the Nursing team and the physicians, which reinforces the need of paying attention to this aspect ${ }^{(15)}$.

In this sense, the WHO released a guide on mental health care during the pandemic, which includes guidelines both for health professionals and for the general population. These guidelines include reading fewer pieces of news that can cause anxiety or stress, selecting only reliable sources of information to get updated, thus avoiding the "unnecessary bombardment" of news; taking work breaks, even when working in the home office modality; keeping a healthy diet and regular sleeping hours; practicing physical exercise or meditation; and also keeping in contact with family members through the online environment, respecting physical distance. These are some care measures that may help them recognize and resignify their feelings and internal demands, aiming at their well-being and mental sanity ${ }^{(2)}$.

\section{SOME CONSIDERATIONS}

This reflection aimed to promote a discussion on the mental health of the Nursing professionals in the midst of the Coronavirus pandemic, which is currently on the rise both in Brazil and in the world.

Thinking about the mental health of the Nursing professionals becomes a reflection that must go beyond health promotion: it is an issue of management, strategy, and care with the workers. Discussing this theme in the midst of a pandemic can ensure that the Nursing workers have better conditions to assist the population.

The devaluation of Nursing is a problem that was noticed much before the current scenario but, it is in the midst of chaos that the world can look at its representativeness and importance from a more sensitive perspective. Mental health must be prioritized in this moment, since it possibly will leave irreparable marks on many professionals who are working in the front line.

Each health service, considering its singularity, should engage with its staff in the search for strategies that are currently pertinent and feasible, minimizing the negative and frightening effects. Therefore, it is necessary that the mental health of the Nursing professionals be listed as one of the priorities for the health managers, guaranteeing strategies and public policies that ensure sanity and maintain the integrity of the team that is in the front line against the current pandemic.

\section{REFERENCES}

1. Schmidt B, Crepaldi MA, Bolze SDA, Neiva-Silva L, Demenech LM. Saúde mental e intervenções psicológicas diante da pandemia do novo coronavírus (COVID-19). Estud Psicol. (Campinas). 2020;37:e200063. doi: https://doi. org/10.1590/1982-0275202037e200063

2. World Health Organization (CH). Geneva: WHO; 2020 [cited 2020 Apr 07]. Coronavirus disease (COVID-19) pandemic; [about 1 screen]. Available from: https://www.who.int/emergencies/diseases/novel-coronavirus-2019

3. Ministério da Saúde (BR). Brasília: Ministério da Saúde; c2020 [cited 2020 Apr 16]. Saúde lança campanha de prevenção ao coronavírus; [about 1 screen] Available from: https://www.saude.gov.br/noticias/agencia-saude/ 46458-saude-lanca-campanha-de-prevenca0-a0-coronavirus

4. Souza LPS, Souza AG. Enfermagem brasileira na linha de frente contra o novo Coronavírus: quem cuidará de quem cuida? J Nurs Health. 2020;10(4):20104005. doi: https://doi.org/10.15210/jonah.v10i4.18444

5. Choi KR, Skrine Jeffers K, Logsdon MC. Nursing and the novel coronavirus: risks and responsibilities in a global outbreak. J Adv Nurs. 2020;76(7):1486-7. doi: https://doi.org/10.1111/jan.14369

6. Lai J, Ma S, Wang Y, Cai Z, Hu J, Wei N, et al. Factors associated with mental health outcomes among health care workers exposed to coronavirus disease 2019. JAMA Netw Open. 2020;3(3):e203976. doi: https://doi.org/10.1001/ jamanetworkopen.2020.3976

7. Jackson D, Bradbury-Jones C, Baptiste D, Gelling L, Morin K, Neville S, et al. Life in the pandemic: some reflections on nursing in the context of COVID-19. J Clin Nurs. 2020;(29):2041-3. doi: https://doi.org/10.1111/jocn.15257

8. Torales J, O'Higgins M, Castaldelli-Maia JM, Ventriglio A. The outbreak of COVID-19 coronavirus and its impacton global mental health. Int J Soc Psychiatry. 2020;66(4):317-20. doi: https://doi.org/10.1177/0020764020915212

9. Conselho Federal de Enfermagem (BR). Resolução Cofen No 634/2020. Autoriza e normatiza, "ad referendum" do Plenário do Cofen a teleconsulta de enfermagem como forma de combate à pandemia provocada pelo novo coronavírus (Sars(ov-2), mediante consultas, esclarecimentos, encaminhamentos e orientações com uso de meios tecnológicos, e dá outras providências. Brasília, DF: COFEN, 2020 [cited 2020 May 03]. Available from: http://www.cofen.gov.br/resolucaocofen-no-0634-2020_78344.html

10. Inter-Agency Standing Committee (CH). IASC's Reference Group on Mental Health and Psychosocial Support. Interim briefing note addressing mental health and psychosocial aspects of COVID-19 outbreak. Geneva: IASC; 2020 [cited 2020 Apr 15]. Available from: https://interagencystandingcommittee.org/iasc-referencegroup-mental-health-and-psychosocial-support-emergency-settings/ interim-briefing

11. Conselho Federal de Enfermagem (BR). Brasilia, DF: COFEN; c2020 [citado 2020 mai 03]. Após fiscalizações, conselhos direcionam 4.533 denúncias a órgãos governamentais; [about 1 screen]. Available from: http://www.cofen. gov.br/apos-fiscalizacoes-conselhos-direcionam-4-533-denuncias-d-orgaosgovernamentais_80324.html

12. Ministério da Educação (BR). Portaria no 374, de 3 de abril de 2020. Dispõe sobre a antecipação da colação de grau para os alunos dos cursos de Medicina, Enfermagem, Farmácia e Fisioterapia, exclusivamente para atuação nas ações de combate à pandemia do novo coronavírus - Covid-19. Diário Oficial da União. 2020abr6 [cited 2020 May 10];158(66Seção 1):66. Available from: http://www. in.gov.br/en/web/dou/-/portaria-n-374-de-3-de-abril-de-2020-251289249 
13. Ornell F, Halpern SC, Kessler FHP, Narvaez JCM. The impact of the COVID-19 pandemic on the mental health of healthcare professionals. Cad Saúde Pública. 2020;36(4):e00063520. doi: https://doi.org/10.1590/0102-311X00063520

14. Spoorthy MS, Pratapa SK, Mahant S. Mental health problems faced by healthcare workers due to the COVID-19 pandemic- a review. Asian J Psychiatr. 2020;51:102119. doi: https://doi.org/10.1016/j.ajp.2020.102119
15. Ornell F, Schuch JB, Sordi AO, Kessler FHP. "Pandemic fear" and COVID-19: mental health burden and Strategies. Braz J. Psychiatry. 2020;42(3):232-5. doi: https://doi.org/10.1590/1516-4446-2020-0008

\section{- Corresponding author:}

Maria de Lourdes Custódio Duarte

E-mail:malulcd@yahoo.com.br

Associate editor:

Dagmar Elaine Kaiser

Editor-in-chief:

Maria da Graça Oliveira Crossetti 